\title{
Added Values of the Local Timbers Materials for Main Bridge Frame Structures Utilizing Laminating Composites Technology
}

\author{
Ari Sandhyavitri ${ }^{1{ }^{*}}$ (1), Fakhri $^{1}$, Rizki Ramadhan Husaini ${ }^{2}$, Indra Kuswoyo ${ }^{1}$, Manyuk Fauzi ${ }^{1}$ \\ ${ }^{1}$ Civil Engineering Department, Engineering Faculty, University of Riau, Kampus Bina Widya Jl. HR Soebrantas KM 12,5 \\ Pekanbaru, 28293 \\ ${ }^{2}$ Civil Engineering Department, Engineering Faculty, University of Abdurrab, Jl. Riau Ujung No. 73 Pekanbaru, 28291
}

\begin{abstract}
The objectives of this article are to seek the opportunity to enhance the local Indonesia timber material physical performances (encompassing the low-class quality of III and IV timbers with the Modulus of Elasticity $(\mathrm{MOE})=5,000-9,000$ $\mathrm{MPa}$ ) utilizing laminated composite technology to become higher-class timber quality (class II) with the Modulus of Elasticity $(\mathrm{MOE})>15,000 \mathrm{MPa}$ so that it can be used as an alternative material for constructing the bridge mainframe structures (girder beams) especially for the Indragiri Hilir regency, Riau Province, Indonesia. This regency needs several hundred small-medium bridges for connecting 20 districts, 39 wards, and 197 villages using local materials such as local timbers. This laminating technology is not a new technology but the utilization of this technology for constructing the main bridges structures is challenging and limited to the implementation in the civil construction industrial sector. This study composed 2 types of the low-class quality (lcq) of timber materials (such as Shorea sp and Shorea peltata Sym) and 2 types of medium class-quality (mcq) ones (Dipterocarpus and Calophyllum) for constructing the main bridge structures. Based on the laboratory test results utilizing $80 \%$ of lcq materials and $20 \%$ mcq ones, these composite timber materials may increase the timbers MOE by $145 \%$ to $166 \%$ from the existing MOE value of the mcq solid timbers. Based on the simulations these laminated composites wooden bridge girders $2 \times(70 \times 20) \mathrm{m}^{2}$, these timber materials have passed all the tests and the application of this technology may improve the lcq timber values and it could be used for an alternative material of the bridge girder's main structures.
\end{abstract}

Key words: added values, composites, technology, laminating, timbers, girders, bridges.

\section{INTRODUCTION}

It was reported that the global growth in timber demand was increased from 334 million $\mathrm{m}^{3}$ (2017) to 341 million $\mathrm{m}^{3}$ (2018) (Canadian Forest Industry, 2019). The requirement of the timber materials type class I-II (Strength class I - II based on PKKI, 1961 and SNI 7973: 2013) [1,2] in Indonesia has been also continuing to increase $[3,4]$. In Indonesia during the 2016-2017 periods, the production of timber logs was estimated at 40 million $\mathrm{m}^{3}$ per year. In fact, the existing plywood timber, sawn-timber, and pulp industries required 75.8 million $\mathrm{m}^{3}$ annually. Hence, there was a lag of $35.8 \mathrm{~m}^{3}$ legal timber logs per year [3].

The decrease in the area of the natural forests in Indonesia at the rate of more than 20 million hectares in 2016-2017 controversial with an increase of timber logs demand. The high demand and the lack of supply of qualified and legal timber materials have implications for increasing the high-quality timber prices. For example the price of the timber quality class II - I per $\mathrm{m}^{3}$ in Riau province currently reached Rp. 4,500,000 - Rp. 8,500,000, hence this caused to increase in wooden bridge costs and an increase in using illegal timber logs [3]. The timber class IV and III prices were about Rp. 2,500,000 per $\mathrm{m}^{3}$, which is far less (50\%) than those the quality class II-I.

Thus, there was a need to seek alternatives timber technology to improve the low-class quality timber materials (class IV and III) to become high-class quality ones (class III) and at affordable prices by utilizing a combination of the existing local timber materials which is relatively low quality and relatively cheaper prices with relatively high-class quality timbers. These combination timbers may be used as the alternative construction material of the girder bridge. Hence this can be performed by the application of laminated timber composite technology $[5,6]$.

The laminated timber composite technology is not new because this technology combines materials that were made of two or more types of timbers that remain separate and different at the macroscopic level but mechanically can be considered as an integrated component [7-9].

It is interesting to investigate to what extent this composite technology in increasing the strength and physical properties of the low-class quality timbers to become medium or high-class quality timbers, which are ultimately these composite materials can be used as materials for constructing bridge girders [5]. The results of

$\begin{array}{ll}\text { Received } & \text { : September 08, 2020 } \\ \text { Revised } & \text { : October 04, 2020 } \\ \text { Accepted } & : \text { November 13, } 2020\end{array}$




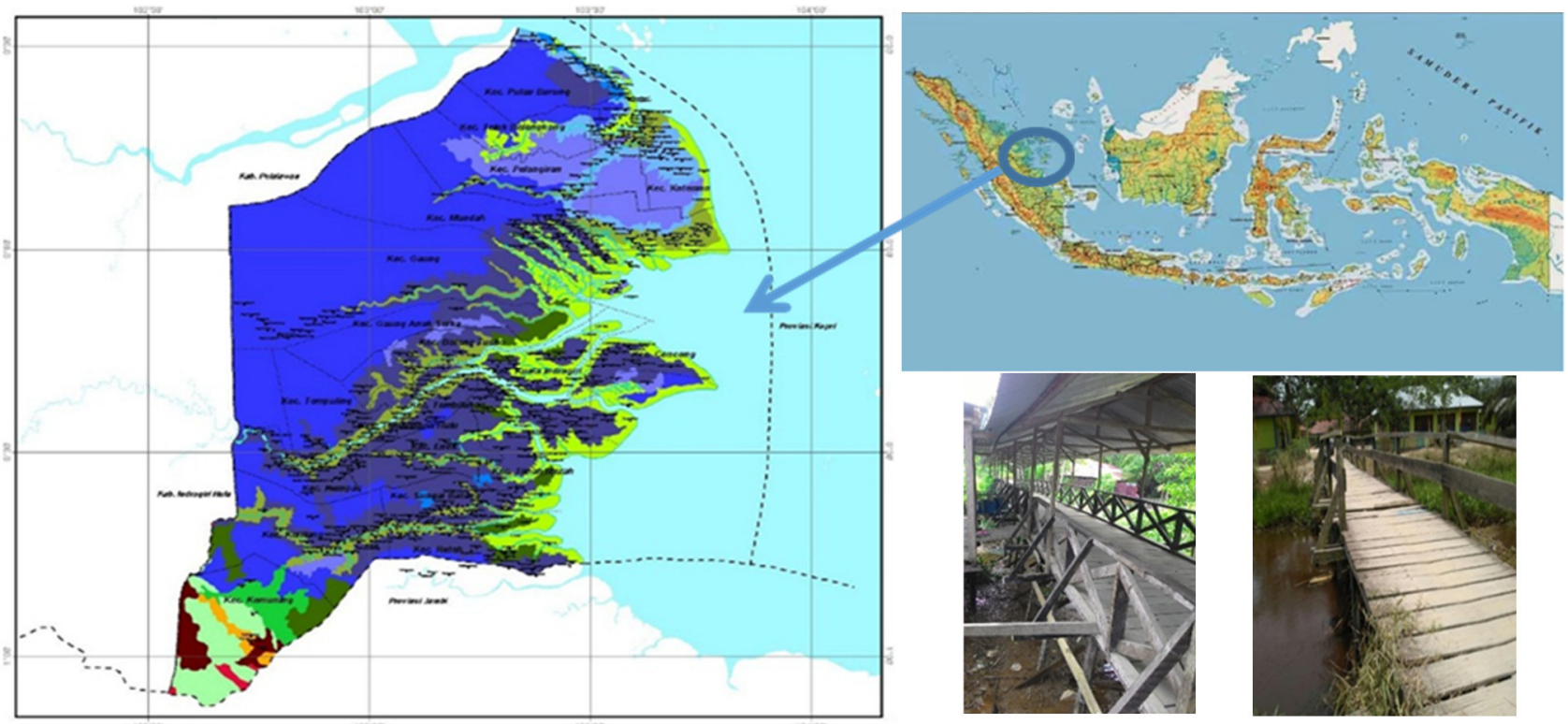

Fig. 1. Location of the study area in Indragiri Hilir, Indonesia.
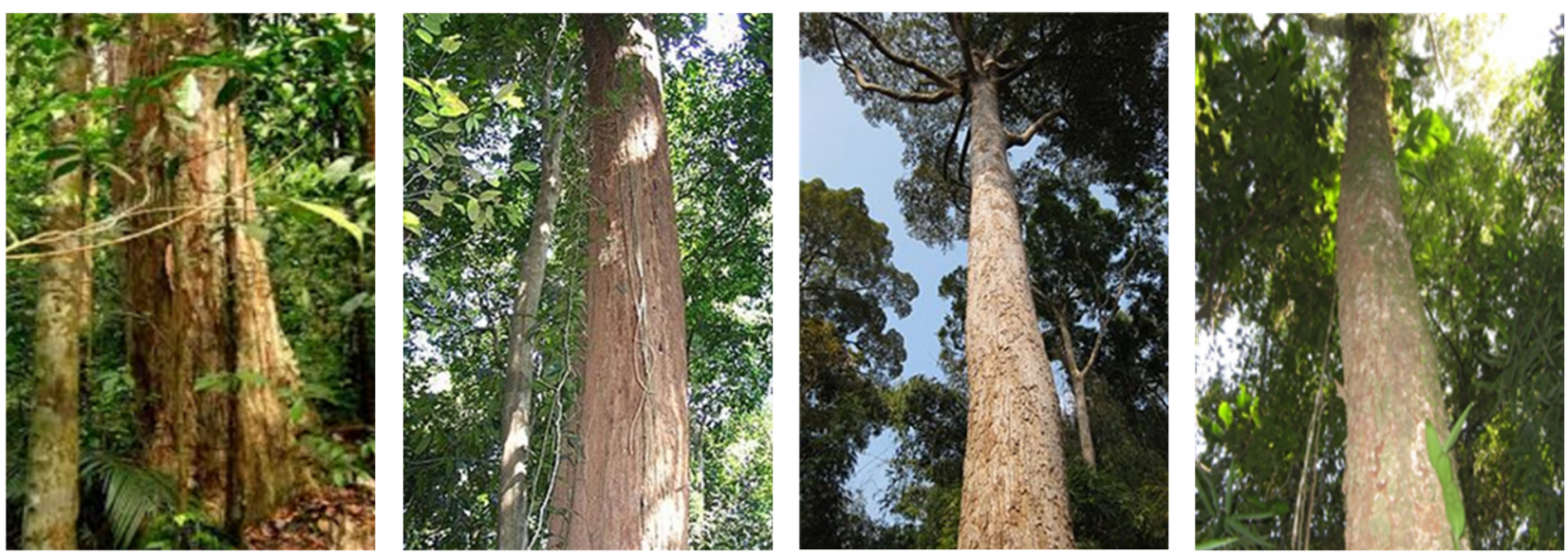

Fig. 2. (a) Shorea sp, (b) Shorea peltata Sym, (c) Dipterocarpus, (d) Calophyllum

this investigation are expected may contribute to the body of knowledge in the area of composite materials for the civil engineering construction industry.

These article objectives are to explore the opportunity for enhancing the added values of the low- class quality of III and IV timber materials in Indonesian, especially in Indragiri Hilir to become a higher-class quality one (class II) utilizing laminated composite. The end of the result materials will be simulated to be used for constructing the bridge's mainframe structures.

The case study area was located in Indragiri Hilir, Riau Province, Indonesia. Approximately $93.31 \%$ of the area of Indragiri Hilir Regency is situated on the river deposit areas, swamp, and wetland, with peat soil and brackish forest covering the coast of the Indragiri River. This area encompasses $12,614 \mathrm{~km}^{2}$ with an average altitude of $0-3$ meters above the mean sea level. The Indragiri Hilir Regency has many rivers and thousands of $\mathrm{km}$ of ditches so that this area is known as "Thousand Ditches Land (Negeri Seribu Parit)" so that it requires several hundred bridges especially small-medium bridges (length $<10 \mathrm{~m}$ ) to connect 20 districts, 39 wards, and 197 villages. Commonly, the small-medium bridges were constructed using concrete materials that were experienced to collapse within 2-5 years periods as the effect of low bearing capacity soils so that the peat soils do not have any sufficient bearing capacity in supporting the concrete bridge foundations. The application of medium-high-quality timbers (class I-II) to construct wooden bridges in these areas was experiencing difficulty to purchase legally, and the costs were relatively expensive. Hence this is important to construct the bridge using low-and medium quality timbers that are available locally in the market and relatively inexpensive.

\section{METHODOLOGY}

The samples of timber material were obtained come from Indragiri Hulu District, Riau Province, Indonesia. The timber materials consist of timber classes of II, III, and IV, Epoxy Resin and Hardener, reinforcing sheets (mat) from polypropylene material [10-13].

This study composed 2 types of low-class quality (lcq) of timber materials (such as Shorea $s p$ and Shorea peltata Sym) and 2 types of medium-class quality (mcq) ones 
(Dipterocarpus and Calophyllum) for constructing the main bridge structures (i.e. girder beams). In Indonesia, Shorea $s p$ is well known as Meranti Merah, and Shorea peltata Sym is known as Meranti Kuning. These two types of timbers are often to be used as the main construction structure materials.

State of the arts in the application of the low-medium timbers has historically been used as non-main construction materials such as partitions and the floor surface. This study will explore the added value in using these materials as a main structural material for bridge mainframes. It was also acknowledged that Dipterocarpus is known as Keruing and Calophyllum is known as Kuras. Both timbers are classified as fast-growing trees and very rare to be applied in constructing bridge frame structures. Hence, this research study may challenge the academic approaches in developing a low-class timber material to become high-class timber materials that can be used as a structural material.
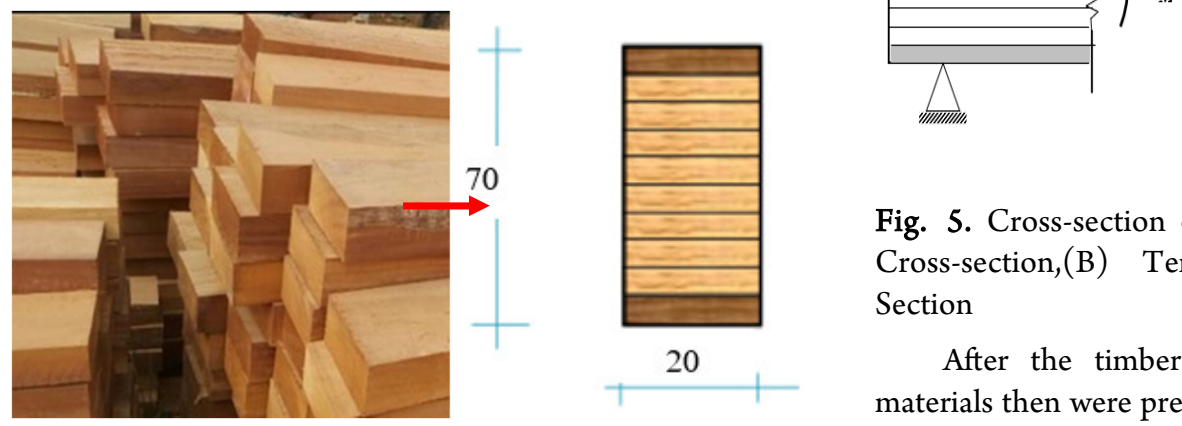

the shear and flexural forces test and loads test before they can be recommended to apply in the construction industry area [14]. The shear forces that occur in the beam structure can be either vertical or horizontal shear forces, the maximum horizontal shear stress will occur on the neutral axis of the cross-section of the beam [15]. The behavior of shear stresses in the beam is illustrated in the following figure (figure 4).

The composite beams can be formed with two different qualities of timbers. The high-class quality timbers' strength was placed on the outside (the top and the bottom layers), and the lower-class timber was placed at the inner layers of this composite with lower-class quality timbers $[6,7]$ as shown in figure 5 .

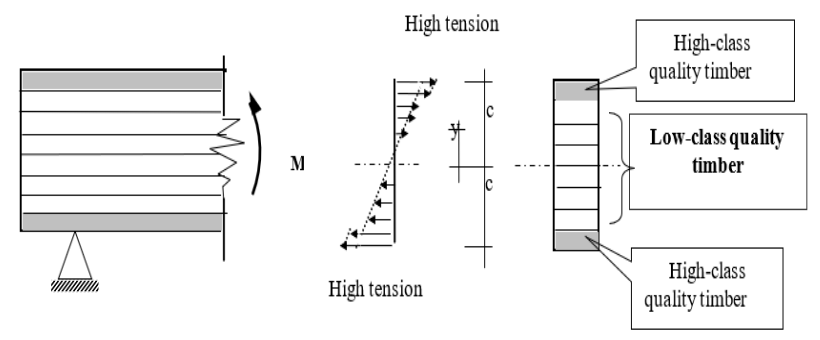

Fig. 5. Cross-section of Glulam Beam; (A) Longitudinal Cross-section,(B) Tension Diagram, (C) Transverse Section

After the timber samples were glued with epoxy materials then were pressed evenly for 24 hours (Figure 6 a, $b, c)$. The samples were also tested for the identification of their mechanical properties using a Universal Testing Machines (UTM) (Figure $6 \mathrm{~d}, \mathrm{e}, \mathrm{f}$ ). The samples were placed in two points with a distance of one-third of the timber spans. The dedicated samples were loaded gradually at a constant loading speed of up to $18 \mathrm{MPa}$ in 30 seconds. Then reduce the loading slowly to $5 \mathrm{MPa}$, then increase the load to $18 \mathrm{MPa}$, and then decrease it again to $5 \mathrm{MPa}$. During the cycle of up-and-down loading tests, the deflections that occur in less than 10 seconds during the loading of $7 \mathrm{MPa}$ and $18 \mathrm{MPa}$ were recorded (Figure $6 \mathrm{f}$ ).

According to Harry Gatterer (2017), there was a success story in establishing an 84 meters high building using timber structures in Vienna, Austria [5]. Hence, there was a proves that the timber could be the main structure for civil construction materials as long as they pass the loading test standards.

Muthmainnah (2014) has conducted a test that results in the compressive strength value of laminated wood depending on the position of the load on the timber surface [16]. The compressive strength with the position of the load plate in the middle of the laminated timber surface produces a higher compressive strength value compared to laying the load on the edge of the laminated timber surface.

However, it was also identified that the laminated timbers may have some weaknesses including this material are relatively easy to cause fires. Harry Gatterer (2017) and Muthmainnah (2014) study tested various cross-laminated timbers for the structural columns and wooden panels. The results showed that the materials were relatively poor in resisting any fire occurrences as the behavior of the adhesive used to bind cross-laminated is prone to cause fires $[17,18]$ 

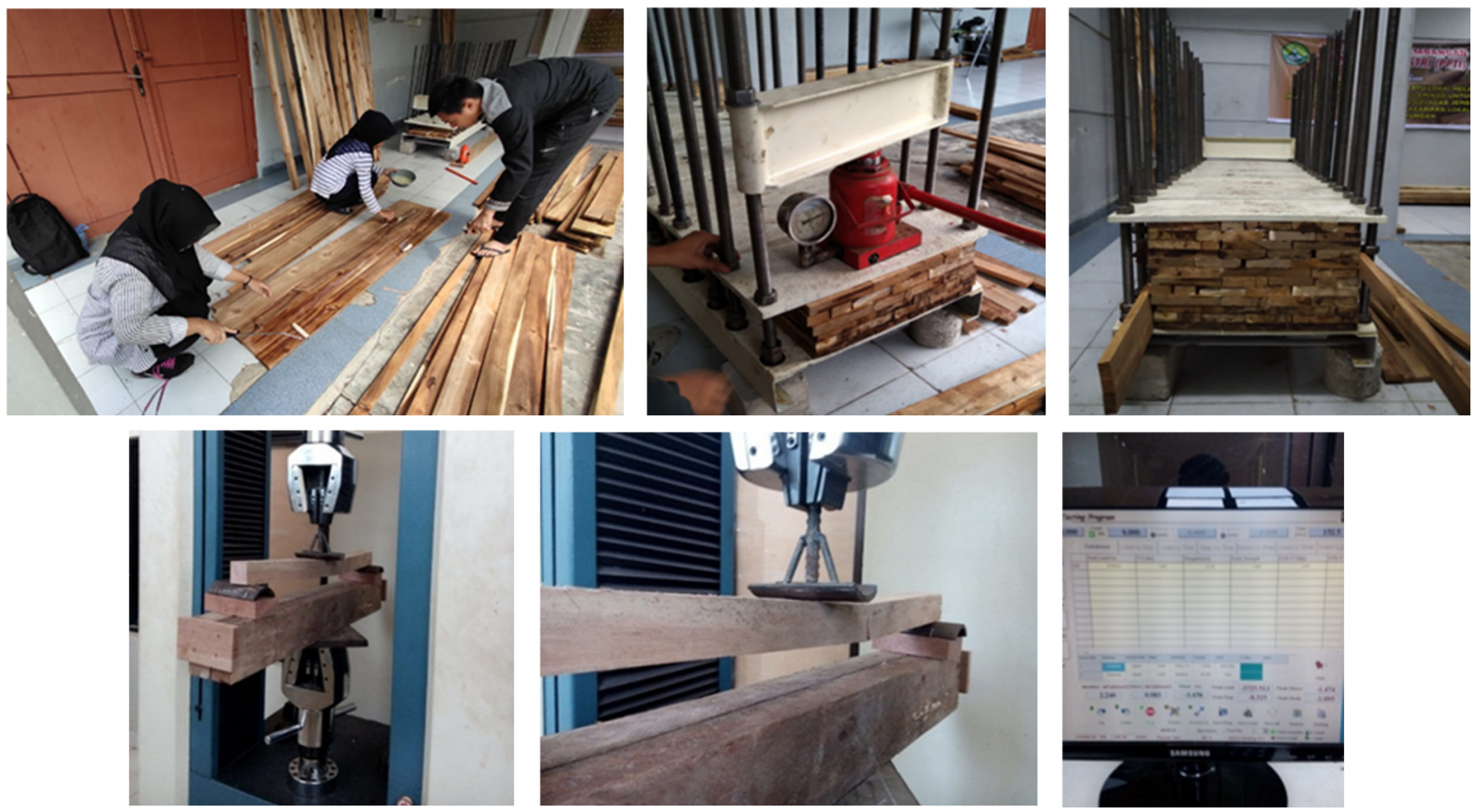

Fig. 6. Timber Samples and Mechanical testing of laminated wood samples using a UTM machine

Table 1 Data of MOE Test Results Based on SNI 03-3960-1995

\begin{tabular}{|c|c|c|c|c|c|c|c|}
\hline No & Wood Type & Sample Code & Newton $(\mathrm{N})$ & Deflection $(\mathrm{mm})$ & MOE (Mpa) & E Average & Quality Code \\
\hline 1 & \multirow{3}{*}{ Dipterocarpus } & KR-1 & 5500 & 7.8 & 12.381 & \multirow{3}{*}{12.797} & \multirow{3}{*}{ E13 } \\
\hline 2 & & KR-2 & 3500 & 5 & 12.291 & & \\
\hline 3 & & KR-3 & 6250 & 8 & 13.718 & & \\
\hline 4 & \multirow{3}{*}{ Calophyllum } & KS-1 & 7500 & 12.5 & 10.535 & \multirow{3}{*}{12.650} & \multirow{3}{*}{ E13 } \\
\hline 5 & & $\mathrm{KS}-2$ & 10000 & 13 & 13.507 & & \\
\hline 6 & & KS-3 & 8000 & 10.1 & 13.908 & & \\
\hline 7 & \multirow{3}{*}{ Shorea $s p$} & MR-1 & 1400 & 3 & 8.194 & \multirow{3}{*}{7.706} & \multirow{3}{*}{ E8 } \\
\hline 8 & & MR-2 & 1800 & 4 & 7.902 & & \\
\hline 9 & & MR-3 & 800 & 2 & 7.024 & & \\
\hline 10 & \multirow{3}{*}{$\begin{array}{l}\text { Shorea peltata } \\
\text { Sym }\end{array}$} & MD-1 & 1600 & 6.05 & 4.644 & \multirow{3}{*}{5.060} & \multirow{3}{*}{ E6 } \\
\hline 11 & & MD-2 & 1800 & 6 & 5.628 & & \\
\hline 12 & & MD-3 & 1500 & 5 & 5.628 & & \\
\hline 13 & \multirow{3}{*}{$\begin{array}{l}\text { Calophyllum - } \\
\text { Shorea peltata } \\
\text { Sym }\end{array}$} & KS-MD-1 & 4000 & 8.2 & 8.565 & \multirow{3}{*}{8.415} & \multirow{3}{*}{ E9 } \\
\hline 14 & & KS-MD-2 & 3600 & 8 & 7.902 & & \\
\hline 15 & & KS-MD-3 & 5000 & 10 & 8.780 & & \\
\hline 16 & \multirow{3}{*}{$\begin{array}{l}\text { Dipterocarpus } \\
\text { Shorea } s p\end{array}$} & KR-MD-1 & 3900 & 6 & 11.413 & \multirow{3}{*}{11.194} & \multirow{3}{*}{ E10 } \\
\hline 17 & & KR-MD-2 & 2250 & 4 & 9.877 & & \\
\hline 18 & & KR-MD-3 & 3500 & 5 & 12.291 & & \\
\hline
\end{tabular}

$K R=$ Dipterocarpus (Kruing) timber $; K S=$ Calophyllum (Kuras) timber, MR = Shorea sp (Meranti Merah) timber; MD = Shorea peltata Sym (Meranti Kuning) timber 


\section{RESULTS AND DISCUSSION}

This study conducted various tests for composite laminated timbers (glulam) using bending and shear tests. Then the results were simulated using vehicle standard axle load encompassing dead load and life load.

\subsection{Bending Strength Test Results}

Based on the test results for the beam flexural test (referring to the ASTM D 143-94 standard) [19], it was identified that high-class quality timbers such as Dipterocarpus and Calophyllum (Keruing and Kuras timbers) were classified as E13 timber quality code values. Meanwhile for low-class quality timbers such as Shorea $s p$ and Shorea peltata Sym (Meranti Merah and Meranti Kuning) timber were classified as E8 and E6 timber quality ones respectively.

A combination of $20 \%-80 \%$ Calophyllum (Kuras) Shorea peltata Sym (Meranti Kuning) Timber composites yielded a MOE of $8,415 \mathrm{Mpa}(84,150 \mathrm{Kg} / \mathrm{cm} 2)$. The composite combination of Dipterocarpus (Keruing Timber) - Shorea sp (Meranti Merah) 20\%-80\% yielded an MOE of $11,194 \mathrm{Mpa}(111,940 \mathrm{~kg} / \mathrm{cm} 2)$.

Based on the test results of Shorea peltata Sym timber as much as $80 \%$ and $20 \%$ of Calophyllum, it was obtained that this composite may increase its strength to become E9 timber quality code (compared to Shorea peltata Sym solid timber the timber quality is E6). The composite of Shorea $s p$ timber $80 \%$ and Dipterocarpus 20\% increased the timber quality to become E10 (compared to the results of solid Shorea $s p$ timber test timber quality of E8). The timber quality codes of E6, E8, E9, and E10 were based on PPKI1961 codes [1].

Thus it can be summarized that the timber laminate composite technology utilizing low and high-class quality of timbers as a beam composite was able to increase the flexural strength and modulus of elasticity of timber material from an average of 5,080 MPa (Shorea peltata Sym) to 8,415 MPa (Composite), and from an average of 7,705 MPa to 11,194 $\mathrm{MPa}$ as shown in Table 1 and Figure 7.

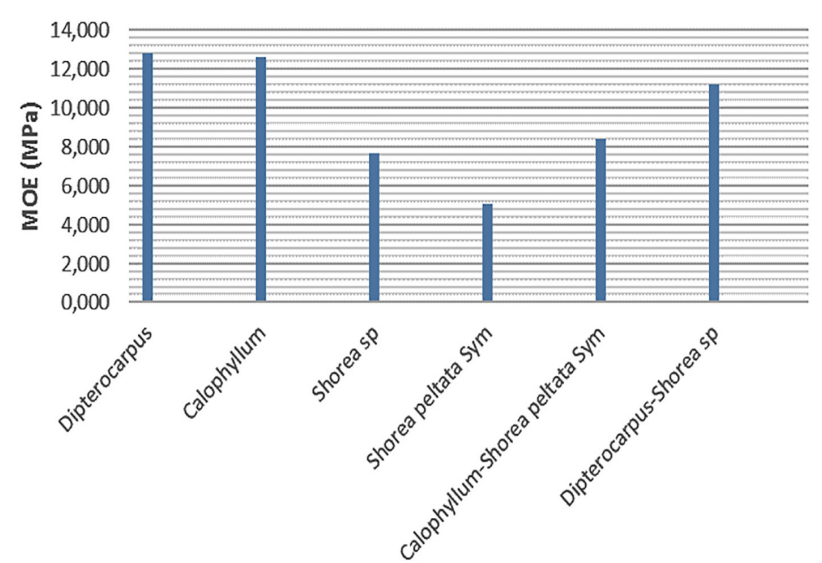

Fig. 7. MOE Test Results Based on SNI 03-3960-

Table 1 and Figure 7 stated that the MOE of laminated composite timber materials (with a proportion of $20 \%$ Dipterocarpus and $80 \%$ Shorea $s p$ ) increased by $166 \%$ from the existing solid Shorea $s p$ timber MOE. The combination of 20\% Calophyllum timber with Shorea peltata Sym timber could increase the MOE strength by $145 \%$ from the existing solid Shorea peltata Sym timber.

Beam flexural test results referring to ASTM D 143-94 are generally obtained for Dipterocarpus and Calophyllum timber, Shorea $s p$, and Shorea peltata $S_{y m}$ which have a match between the Modulus of Elasticity (MOE) and Modulus of Rigidity (MOR) strength, while the MOR strength of Calophyllum timber is higher than that of Dipterocarpus timber one. It can be stated that the contribution of higher-class quality timbers is very dominant affecting the ductile behavior and flexural strength of the tested composite timber beams. Thus it can be summarized that an increase in MOE and MOR strengths of these laminated composite timbers is significant and can be recommended to apply as the main structure for bridge girder materials (Table 2 and Figure 8 ).

Table 2 and Figure 8 show that the Dipterocarpus and Calophyllum timber flexural tests have a ductile nature performance which can bear the relatively large stress-strain forces.

Shorea $s p$ and Shorea peltata Sym are more likely to be more brittle, and lower in bearing stress-strain load. After compressing compression load tests were conducted these both timbers were damage within similar areas at the upper side of timber layers (Figures 9 and 10).

Table 2 Data of MOR Test Results Based on ASTM D 14394

\begin{tabular}{|c|c|c|c|c|}
\hline No & Wood Type & $\begin{array}{l}\text { Sample } \\
\text { Code }\end{array}$ & $\begin{array}{l}\text { MOR } \\
(\mathrm{Mpa})\end{array}$ & $\begin{array}{c}\text { MOR } \\
\text { Average } \\
\text { (Mpa) }\end{array}$ \\
\hline 1 & \multirow{3}{*}{ Dipterocarpus } & KR-1 & 86.48 & \multirow{3}{*}{89.32} \\
\hline 2 & & KR-2 & 73.69 & \\
\hline 3 & & KR-3 & 107.79 & \\
\hline 4 & \multirow{3}{*}{ Calophyllum } & $\mathrm{KS}-1$ & 78.43 & \multirow{3}{*}{100.55} \\
\hline 5 & & $\mathrm{KS}-2$ & 106.18 & \\
\hline 6 & & KS-3 & 117.05 & \\
\hline 7 & \multirow{3}{*}{ Shorea $s p$} & MR-1 & 31.70 & \multirow{3}{*}{35.27} \\
\hline 8 & & MR-2 & 34.58 & \\
\hline 9 & & MR-3 & 39.52 & \\
\hline 10 & \multirow{3}{*}{$\begin{array}{l}\text { Shorea peltata } \\
\text { Sym }\end{array}$} & MD-1 & 27.89 & \multirow{3}{*}{28.36} \\
\hline 11 & & MD-2 & 34.96 & \\
\hline 12 & & MD-3 & 22.24 & \\
\hline 13 & \multirow{3}{*}{$\begin{array}{l}\text { Calophyllum - } \\
\text { Shorea peltata } \\
\text { Sym }\end{array}$} & KS-MD-1 & 49.48 & \multirow{3}{*}{45.43} \\
\hline 14 & & KS-MD-2 & 36.80 & \\
\hline 15 & & KS-MD-3 & 50.01 & \\
\hline 16 & \multirow{3}{*}{$\begin{array}{l}\text { Dipterocarpus } \\
\text { Shorea } s p\end{array}$} & KR-MD-1 & 60.16 & \multirow{3}{*}{59.03} \\
\hline 17 & & KR-MD-2 & 50.64 & \\
\hline 18 & & KR-MD-3 & 66.29 & \\
\hline
\end{tabular}




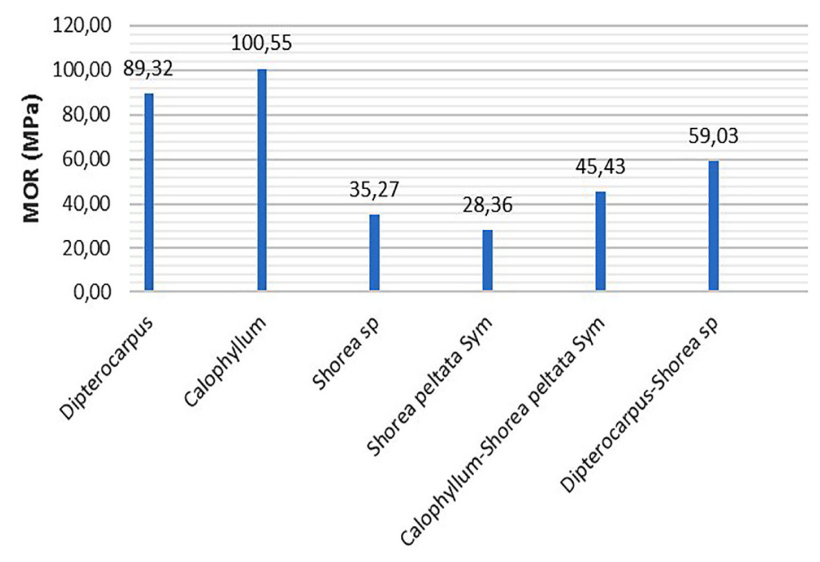

Fig. 8. MOR Test Results Based on ASTM D 143-94.

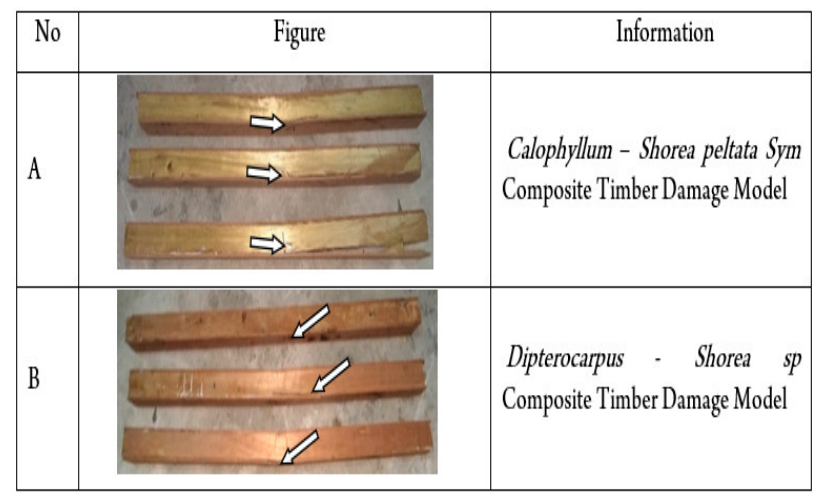

Fig. 9. Type of timber and composite damage

The results of the Shorea peltata Sym timber beam (80\%) test composited with Calophyllum timber (20\%) showed that the model of damage started to occur at the bottom layer of the Shorea peltata Sym timber, then it was followed by the release of a layer of the glued timber that spreads along with the timber layers (Figure 6).

The results of flexural testing of Dipterocarpus timber composites of $20 \%$ or $1 / 5$ part with Shorea $s p$ timber ( $80 \%$ ) obtained the type of flexural damage type where the initial damage occurred on the bottom Keruing timber fiber as shown in Figure Based on the results of the MOR test and load-deflection relationship graph shows a relatively large increase in deformation and ductile behaviors, this is due to the contribution of high-quality timber layers (Dipterocarpus and Calophyllum) which are more resilient compared to low-quality timber species. The damage areas were drawn in Figure 9.

\subsection{Shear Strength Test Results}

Tests of timber laminated sliding blocks that were compiled using two types of adhesives (Epoxy-bond Brand adhesive based on Epoxy and Cross-bond X4 based on PVAC ones) have yielded the following results (Table 3 ).

Based on Table 3, as well as Figure 10 it can be stated that the results of the shear strength test results for the Dipterocarpus and Shorea peltata Sym timber types are eligible for Epoxybond and Cross-bond X4 adhesive types, while for the Calophyllum and Shorea $s p$ timber types do not meet the requirements. For gluing using Crossbond X4 adhesives are eligible for all types of the tested timbers (Figure 10).

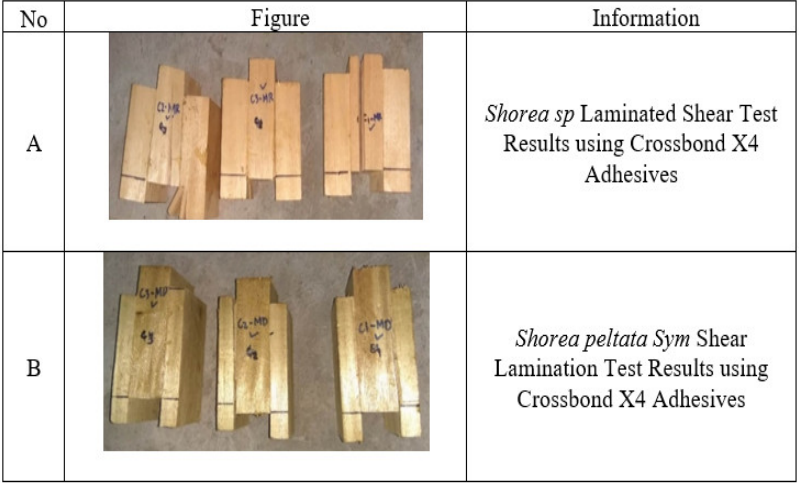

Fig. 10. Timber shear and lamination test.

In this study wooden bridge modeling was carried out to provide a simple design description of a $10 \mathrm{~m}$ short span wooden bridge, span width, (B) $2.75 \mathrm{~m}$, girder size: $\mathrm{h}=0.7$ $\mathrm{m}$; $\mathrm{b}=0.4 \mathrm{~m}$ (double girder $70 / 20 \mathrm{~cm} 2$ ), timber density 800 $\mathrm{kg} / \mathrm{m} 3$, floor thickness: $0.03 \mathrm{~m}$, the number of girder 4 pieces (Figure 11).
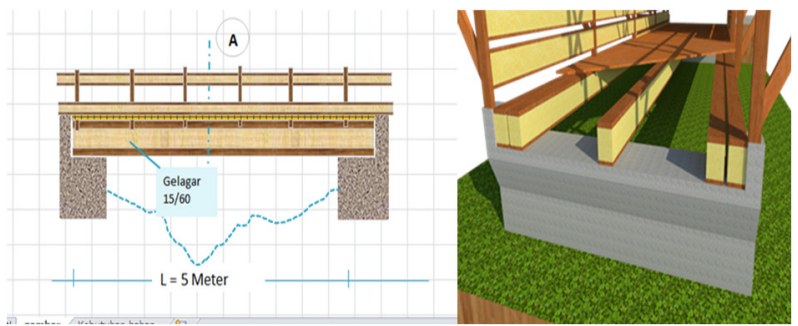

Figure 11. Model Bridge and timber bridge girders

Bridge Structure Calculation Analysis:

Data input :

Length of Span, $\mathrm{L} \quad: 10 \mathrm{~m}$

The width of the bridge, $B: 2.75 \mathrm{~m}$

Size of girder $\quad: \mathrm{h}=0.7 \mathrm{~m} ; \mathrm{b}=0.4 \mathrm{~m}$ (The girder uses a double 70/20 girder beams)

Specific Gravity $\quad: 800 \mathrm{~kg} / \mathrm{m} 3$ (Lab tests)

Floor thickness: $\quad 0.03 \mathrm{~m}$

Number of girders $\quad: 4$ pieces

1. Dead loads and live loads.

Dead Loads

Timber structural load $=\mathrm{h} \times \mathrm{b} \times$ timber specific gravity $=0.7 \mathrm{mx} 0.4 \mathrm{mx} 800 \mathrm{~kg} / \mathrm{m}^{3}$

$=224 \mathrm{~kg} / \mathrm{m}$

Bridge Floor Weight $=$ timber specific gravity $\mathrm{x}(\mathrm{B} / 4) \mathrm{x}$ timber thichness

$=800 \mathrm{~kg} / \mathrm{m}^{3} \times(2.75 / 4) \times 0,03 \mathrm{~m}$

$=16,5 \mathrm{~kg} / \mathrm{m}$

Total bridge dead loads $=240,5 \mathrm{~kg} / \mathrm{m}$

$\underline{\text { Live loads }}$

Point loads with the assumptions of $\mathrm{p}$ loads $=4.36$ ton (Based on the $66 \%$ of the equivalent single axle load (for rear wheel excel truckload) of $1.2 \mathrm{~L}$ with the total truck weight of 6.6 ton was $66 \% \times 6.6$ ton $=4.36$ ton) (Fig. 12). 
Table 3 Data on Shear Strength Test Results

\begin{tabular}{|c|c|c|c|c|c|c|}
\hline No & Type of Adhesive & Wood Type & Sample Code & $\begin{array}{l}\text { Shear } \\
\text { Stress } \\
(\mathrm{Mpa})\end{array}$ & $\begin{array}{c}\text { Shear Stress } \\
\text { Avergae (Mpa) }\end{array}$ & Quality Code \\
\hline 1 & \multirow{12}{*}{ Epoxy } & \multirow{3}{*}{ Dipterocarpus } & KR-1 & 16.28 & \multirow{3}{*}{14.18} & \multirow{3}{*}{ E13 } \\
\hline 2 & & & KR-2 & 9.75 & & \\
\hline 3 & & & KR-3 & 16.51 & & \\
\hline 4 & & \multirow{3}{*}{ Calophyllum } & $\mathrm{KS}-1$ & 4.24 & \multirow{3}{*}{3.91} & \multirow{3}{*}{ E13 } \\
\hline 5 & & & KS-2 & 2.78 & & \\
\hline 6 & & & KS-3 & 4.72 & & \\
\hline 7 & & \multirow{3}{*}{ Shorea $s p$} & MR-1 & 2.73 & \multirow{3}{*}{3.32} & \multirow{3}{*}{ E9 } \\
\hline 8 & & & MR-2 & 3.91 & & \\
\hline 9 & & & MR-3 & 3.31 & & \\
\hline 10 & & \multirow{3}{*}{ Shorea peltata Sym } & MD-1 & 6.34 & \multirow{3}{*}{5.46} & \multirow{3}{*}{ E8 } \\
\hline 11 & & & MD-2 & 6.75 & & \\
\hline 12 & & & MD-3 & 3.29 & & \\
\hline 1 & \multirow{12}{*}{ Crossbond X4 } & \multirow{3}{*}{ Dipterocarpus } & KR-1 & 5.44 & \multirow{3}{*}{6.14} & \multirow{3}{*}{ E13 } \\
\hline 2 & & & KR-2 & 12.97 & & \\
\hline 3 & & & KR-3 & 0.01 & & \\
\hline 4 & & \multirow{3}{*}{ Calophyllum } & KS-1 & 4.37 & \multirow{3}{*}{5.43} & \multirow{3}{*}{ E13 } \\
\hline 5 & & & KS-2 & 6.35 & & \\
\hline 6 & & & KS-3 & 5.58 & & \\
\hline 7 & & \multirow{3}{*}{ Shorea $s p$} & MR-1 & 3.70 & \multirow{3}{*}{5.33} & \multirow{3}{*}{ E9 } \\
\hline 8 & & & MR-2 & 2.94 & & \\
\hline 9 & & & MR-3 & 9.35 & & \\
\hline 10 & & \multirow{3}{*}{ Shorea peltata Sym } & MD-1 & 4.38 & \multirow{3}{*}{6.48} & \multirow{3}{*}{ E8 } \\
\hline 11 & & & MD-2 & 8.24 & & \\
\hline 12 & & & MD-3 & 6.83 & & \\
\hline
\end{tabular}

The average truck total loads in Indragiri Hilir, 2019 will pass the dedicated bridge was 6.6 ton



Fig. 12. Distribution of the axle loads (front and rear wheels).

Uniform q load of 0.80 ton $/ \mathrm{m}$ (or $800 \mathrm{~kg} / \mathrm{m}$ timber specific gravity)

Floor wide of the bridge $<5 \mathrm{~m}$, then:

$\mathrm{p}$ loads $=4.36$ ton dan $\mathrm{q}$ loads $=0.80$ ton $\mathrm{m}$

$$
\begin{aligned}
& \text { shock coefficient } \quad=1.333 \\
& \text { Distance between girder, } \mathrm{s} \quad=0.917 \mathrm{~m} \\
& \text { Vehicle loads (D load) } \\
& \text { a. Point loads = }=\mathrm{p} x \text { shock coeff, } \mathrm{x} \mathrm{s} \\
& =4.36 \times 1.333 \times 0.917 \\
& =5.33 \mathrm{ton} \approx 5333.33 \mathrm{~kg} \\
& \text { Total load (1,6 Live Loads })=1.6 \times 5333.33=8,533.33 \mathrm{~kg} \\
& \approx 85,333.33 \mathrm{Nm} \\
& \text { b. Uniform distributed loads }=\mathrm{q} \times \text { shock coeff. } \mathrm{x} \mathrm{s} \\
& =0.80 \times 1.333 \times 0.917 \\
& =0.98 \text { ton } \approx 977.78 \mathrm{~kg} / \mathrm{m} \\
& \text { Total Loads }(1.2 \mathrm{DL}+1.6 \mathrm{LL})=1,853.04 \mathrm{~kg} \\
& \approx 18,530.44 \mathrm{Nm} \text {. }
\end{aligned}
$$


2. Calculating the Internal loads

a. Due to Uniform Loaded

$$
\begin{aligned}
M u & =\frac{q u \cdot l^{2}}{8} \\
M u & =\frac{18530,44 \mathrm{Nm} \cdot 10^{2}}{8} \\
M u & =231 \cdot 630,56 \mathrm{Nm}
\end{aligned}
$$

b. Due to the Point Load

$$
\begin{aligned}
M u & =\frac{q u \cdot l}{4} \\
M u & =\frac{85 \cdot 333,33 \mathrm{Nm} \cdot 10}{4} \\
M u & =213,333 \cdot 33 \mathrm{Nm}
\end{aligned}
$$

So, the total internal forces $\quad=444,963.89 \mathrm{Nm}$

$$
\approx 444,963,888.89 \mathrm{Nmm}
$$

3. Calculating the Girder Dimensions

For girder dimensions try using a 70/20 double girder, then

$$
\begin{aligned}
\mathrm{Fb}^{\prime} & =\mathrm{Fb}(\mathrm{Cm})(\mathrm{Ct})(\mathrm{Ci})(\mathrm{Cf})(\mathrm{Cfu})(\mathrm{Cr})(\mathrm{Ci}) \\
\mathrm{Fb}^{\prime} & =27(0.8)(1)(1)(1)(1)(1.15)(1) \\
\mathrm{Fb}^{\prime} & =24.84 \mathrm{Mpa} \\
\text { S need } & =\frac{M u}{F b^{\prime}} \\
\text { S need } & =\frac{444,963,888.89 \mathrm{Nmm}}{24.84 \mathrm{Mpa}} \\
\text { S need } & =17,913.20 \mathrm{~mm}^{3}
\end{aligned}
$$

the dimensions of the girder $70 / 20$ (double) are used, then:

$$
\begin{aligned}
& \mathrm{S} \quad=1 / 6 \mathrm{bh}^{2} \\
& \mathrm{~S} \quad=1 / 6400.700^{2} \\
& \mathrm{~S} \quad=32,666.67 \mathrm{~mm}^{3} \\
& \mathrm{~S}>\mathrm{S} \text { need (dimension is ok). } \\
& \text { 4. Checking Beam Bending } \\
& \mathrm{M}^{\prime} \quad=\text { Fb'S } \\
& \mathrm{M}^{\prime} \quad=24.84 \mathrm{Mpa} \times 32.666 .667 \mathrm{~mm} \\
& \mathrm{M}^{\prime} \quad=811,440,000.0 \mathrm{Nmm} \approx 811.44 \mathrm{KNm}
\end{aligned}
$$$$
\mathrm{Mu} \leq \mathrm{M}^{\prime *} \theta \mathrm{b}^{*} \lambda
$$$$
444.96 \leq 811.44 \times 0,85 \times 0,8
$$$$
444.96 \leq 551.78 \text { (bending test is ok) }
$$

5. Checking Beam Shear

Calculating Value, $\mathrm{Vu}$

$\mathrm{Vu} \quad=(18530,44 \times 10 / 2+85333,33 / 2)$

$\mathrm{Vu} \quad=135.318 .89 \mathrm{~N} \approx 135.32 \mathrm{KNm}$

Calculating value, $\mathrm{Fv}^{\prime}$

$$
\begin{array}{ll}
\text { Fv' }^{\prime} & =\mathrm{Fv}(\mathrm{Cm})(\mathrm{Ct})(\mathrm{Ci}) \\
\text { Fv }^{\prime} & =4.8(0.87)(1)(1) \\
\text { Fv }^{\prime} & =4.176 \mathrm{Mpa}
\end{array}
$$

Calculating Value, $V^{\prime}$

$$
\begin{array}{ll}
\mathrm{V}^{\prime} & =2 / 3 F_{V^{\prime} b . d} \\
\mathrm{~V}^{\prime} & =2 / 34,176 \times 700.400 \\
\mathrm{~V}^{\prime} & =779.52 \mathrm{~N} \approx 780 \mathrm{KN}
\end{array}
$$

In Terms of $\mathrm{Vu} \leq \mathrm{V}^{*} \theta \mathrm{v}^{*} \lambda$, so: $\mathrm{Vu} \leq \mathrm{V}^{*} \theta \mathrm{v}^{*} \lambda$
$135.32 \leq 780 * 0.75^{*} 0,8$

$135.32 \leq 468$ (shear test is ok).

Checking the Beam Deflection

$$
\begin{array}{ll}
\text { E1 } & =12,797 \mathrm{Mpa} \\
\mathrm{E} 2 & =7,706 \mathrm{Mpa}
\end{array}
$$

For this reason, the value of transformation (It) is calculated based on the formula,

$$
\text { It }=2\left\{\frac{l}{12} b h_{1}^{3}+b h_{1}\left(\frac{l}{2} h_{1}+\frac{l}{2} h_{2}\right)^{2}\right\} \frac{E_{1}}{E_{2}}+\frac{l}{12} b h_{2}{ }^{3}
$$

Girder size

$$
\mathrm{h}=0,7 \mathrm{~m}=700 \mathrm{~mm} \quad \mathrm{~h} 1=0,1 \mathrm{~m} \times 700 \mathrm{~mm}=70 \mathrm{~mm}
$$$$
\mathrm{b}=0,4 \mathrm{~m}=400 \mathrm{~mm} \quad \mathrm{~h} 2=700-70-70=560 \mathrm{~mm}
$$

Hence,

It $=15,119,430,504.37 \mathrm{~mm}^{4}=1,511,943.05 \mathrm{~cm}^{4}$

Ew' = 7,706 Mpa.

Then the amount of deflection is obtained:

As a result of the distributed load uniform,

$$
\begin{aligned}
\Delta_{l} & =\frac{5 w_{L} L^{4}}{384 E^{\prime} I} \\
\Delta_{l} & =\frac{5 \times 9,8 \times 10.000^{4}}{384 \times 15.119 .430 .504,37 \times 7.706} \\
\Delta_{l} & =10,9273412 \mathrm{~mm} \approx 1.09 \mathrm{~cm}
\end{aligned}
$$

Due to the point load,

$$
\begin{aligned}
\Delta_{l} & =\frac{Q_{u} L^{3}}{48 E \prime I} \\
\Delta_{l} & =\frac{85333,33 \times 10.000^{3}}{48 \times 15.119 .430 .504,37 \times 7.706} \\
\Delta_{l} & =15,2585 \mathrm{~mm} \approx 1.53 \mathrm{~cm}
\end{aligned}
$$

Total of Deflection $=$ Total deflection due to uniform dis tributed loads + Total deflection due to the point load

Total of Deflection $=26.18 \mathrm{~mm}$, while

Deflection of permission $\Delta_{\text {Permission }}=1 / 360=27.78 \mathrm{~mm}$

Total of Deflection < Deflection of Permission

$26.18 \mathrm{~mm} \quad<27.78 \mathrm{~mm}$ (deflection test is ok)

\section{CONCLUSION}

Based on the laboratory and the simulation tests, it was concluded that timber beams which were performed by two different types of timber materials (using a laminated composite technology) could be used for bridge beam materials especially for the wooden bridge structure. The use of a high quality-class II timber material (20\% Dipterocarpus timber) and composited with the low quality-class III (80\% Shorea peltata Sym timber material) could produce higher MOE timbers, which is compatible with $145 \%$ to $166 \%$ of the existing lower-class pure quality of the timber material one. Hence, it is recommended that to perform validations and tests in the relevant environment prior to the implementation of this material to the civil construction engineering area. 


\section{AUTHOR INFORMATION}

\section{Corresponding Author}

*Email : ari.sandhyavitri@eng.unri.ac.id

\section{ORCID}

Ari Sandhyavitri : :0000-0002-3174-5502

\section{ACKNOWLEDGEMENTS}

The authors gratefully acknowledge this research is supported by the Riau Research and Development Agency (Balitbangda), Program Pengembangan Teknologi Industri (PPTI) research grant under the Higher Education Directorate General, Ministry of Research and Technology, Indonesia.

\section{REFERENCES}

[1] Public Work Department, 1961, Peraturan Konstruksi Kayu Indonesia NI-5, PKKI-1961, Departemen Pekerjaan Umum Republik Indonesia, Jakarta.

[2] National Standardization Agency, 2013, Spesifikasi desain untuk konstruksi kayu (SNI 7973:2013), BSN, Bandung.

[3] KLHK, 2018. The State's of Indonesia Forests 2018. Kementerian Lingkungan Hidup dan Kehutanan republik Indonesia

[4] BPS, 2018, Statistics of Forestry Production 2017. Statistic Cbetral Beuro (Badan Pusat Statistik), Republik Indonesia

[5] Harry Gatterer (Editor), 2017, The future of Timber Construction CLT - Cross Laminated Timber, Zukunftsinstitut Österreich $\mathrm{GmbH}$, Rudolfsplatz 12/6, 1010 Vienna, pp.18-27.

[6] Kaw, A.K. 2007. Mechanics of Composites Materials. CRC Press: Boca Raton

[7] Blass, H.J. et. all., 1995, Timber Engineering Step I, First Edition, Centrum Hout, The Netherlands.

[8] Breyer, Donald. E., 1988, Design of Timber Structures, Second Edition, McGraw-Hill, Inc. New York.

[9] Gurfinkel, G., 1981, Timber Engineering, Second Edition, Kendall/Hunt Publishing Company, Dubuque, Iowa.
[10] Witmer Jr., R.W., Manbeck, B. H., Janowiak, J. J., 1999, Partial Composite Action in Hardtimber Glued-Laminated T-Beams, Journal of Bridge Engineering, Volume 4, Issue 1, pp. 23-29.

[11] Hartomo A.J., Rusdiharsono A. dan Hardjanto D., 1992, Memahami Polimer dan Perekat, penerbit Andi offset, Yogyakarta.

[12] Koval'chuk, L.M., dan Baltrushaitis, A.V., 1989, Effect of Timber defect on The Strength of Glue Structure, Izvestiya-Vysshikh-Uchebnykh-Zurnal, No. 3, pp. 76-80.

[13] Prayitno, T. A., 1994, The Effect of White Clay Extention, Particle Size and Glue Spread on Urea Formaldehide-Timber Bond Strength, Bulletin Fakultas Kehutanan, No. 25, pp. 21-42.

[14] Gere, J.M., Timoshenko, S.P., 1987, Mechanics of Materials, First Edition, Wadsworth, Inc., Belmont, California.

[15] Somayaji, S., 1995, Civil Engineering Materials, Prentice Hall, Engletimber, Cliffs, New Jersey.

[16] Muthmainnah., Sadiyo, S., Karlinasari, L., 2014, Kekuatan Tekan Tegak Lurus Serat Cross Laminated Timber (CLT) Tiga Jenis Kayu Rakyat, J. Ilmu Teknol. Kayu Tropis Vol. 12 No.2 Juli 2014, page 134-145

[17] Frangia, A., Fontana, M., Hugib, E., Jübstl, R., 2009, Experimental analysis of cross-laminated timber panels in fire, Fire Safety Journal, Volume 44, Issue 8, November 2009, Pages 1078-1087

[18] Wiesner, F., Bisby, L., 2019, The structural capacity of laminated timber compression elements in fire: A meta -analysis, Fire Safety Journal, Volume 107, July 2019, Pages 114-125

[19] ASTM D143-94, Standard Test Methods for Small Clear Specimens of Timber, ASTM International, West Conshohocken, PA, 2000 Attriution 4.0 International License. 